\title{
Phenotypic Characterization, DNA Similarities, and Protein Profiles of Twenty Sulfur-Metabolizing Hyperthermophilic Anaerobic Archaea Isolated from Hydrothermal Vents in the Southwestern Pacific Ocean
}

\author{
VIGGÓ THÓR MARTEINSSON,${ }^{1}$ LAURENT WATRIN, ${ }^{1}$ DANIEL PRIEUR, ${ }^{1}$ JEAN CLAUDE CAPRAIS, ${ }^{2}$ \\ GÉRARD RAGUÉNĖS, ${ }^{2}$ AND GAËL ERAUSO ${ }^{1 *}$ \\ CNRS UPR 4601, GDR 1006, Station Biologique 29680, Roscoff, ${ }^{1}$ and the Institut Français de Recherche et \\ Exploitation de la Mer (IFREMER) Environment Profond, 29280 Plouzané, ${ }^{2}$ France
}

\begin{abstract}
We performed phenotypic and physiological studies with 20 hyperthermophilic microorganisms isolated from hydrothermal vents located in the North Fiji Basin (southwestern Pacific Ocean) at a depth of $2,000 \mathrm{~m}$. These isolates were strict anaerobes that were regular to irregular coccoids and used elemental sulfur in their metabolism. Growth was observed at temperatures ranging from 50 to $101^{\circ} \mathrm{C}$. The DNA base compositions varied from 43 to $60 \mathrm{~mol} \%$. All of these organisms were heterotrophs and fermented peptides to acetate, isovalerate, isobutyrate, and propionate. They contained both diether and tetraether lipids in their membranes, which indicates that they belong to the domain Archaea. DNA-DNA hybridization experiments revealed that there were two distinct homology groups, which correlated well with results obtained from sodium dodecyl sulfate-polyacrylamide gel electrophoresis of soluble whole-cell proteins, and these groups corresponded to the genera Pyrococcus and Thermococcus. Five isolates exhibited levels of DNA-DNA relatedness with Pyrococcus abyssi ranging from 71 to $100 \%$ and produced almost identical protein patterns. The remaining isolates formed a weakly homogeneous group based on DNA-DNA similarity data and protein patterns; the results of unweighted pair group cluster analyses suggested that these isolates were members of five new species of the genus Thermococcus.
\end{abstract}

Since the first discovery of deep-sea hydrothermal vents near the Galapagos Islands (12) in 1977, several new active vents in the Pacific and Atlantic Oceans have been explored (for a review see reference 42 ). Novel hyperthermophilic archaea (50) have been isolated from these extreme ecosystems and have been described. Some of these organisms have been identified as new species $(13,43)$.

The new isolates that have been described are autotrophs or heterotrophs, but most belong to the group that contains the neutrophilic sulfur metabolizers. This metabolic group includes six genera (the genera Pyrococcus, Thermococcus, Hyperthermus, Pyrodictium, Desulfurococcus, and Staphylothermus) that were first described on the basis of shallow-water isolates $(18,19,47,53,55,56)$. Representatives of all of these genera except the genus Hyperthermus have also been found among the deep-sea isolates and assigned to new species (17, $25,30,41)$. However, several other fully described isolates have not been assigned to previously described or new species, probably because their morphological and physiological features did not distinguish them from each other or previously isolated species $(26,39,40,43,44)$. All of these isolates are regular to irregular cocci that are motile or nonmotile. They are strict anaerobes and metabolize elemental sulfur, although some grow without sulfur and are not strictly sulfur dependent.

In this paper we report and discuss the results of a polyphasic characterization (which included determinations of morphology, physiology, protein profiles, $\mathrm{G}+\mathrm{C}$ contents, and DNA-DNA hybridization data) and tentative identification of 20 anaerobic, chemoorganotrophic, hyperthermophilic, sulfur-

* Corresponding author. Present address: Mikrobiologisches Institut, ETH-Zentrum/LFV, CH-8092 Zürich, Switzerland. Phone: 01632-33-15. Fax: 01-632-11-48. Electronic mail address: erauso@micro. biol.ethz.ch. metabolizing strains that were isolated from the deep-sea hydrothermal vents discovered in 1989 in the southwestern Pacific Ocean.

\section{MATERIALS AND METHODS}

Isolates and reference strains. Samples of hydrothermal fluids, chimney, and invertebrates were collected by using the manned submersible vessel "Nautile" during the cruises designated "Biolau" and "Starmer" organized in 1989 by the Institut Français de Recherche et Exploitation de la Mer (IFREMER) in the Lau Basin (site "Hine Hine"; $22^{\circ} 32^{\prime} \mathrm{S}, 176^{\circ} 43^{\prime} \mathrm{W}$ ) and the North Fiji Basin (site "White Lady"; $16^{\circ} 59^{\prime} \mathrm{S}, 173^{\circ} 55^{\prime} \mathrm{W}$ ), respectively. The maximum temperature of the fluids at the latter site was around $300^{\circ} \mathrm{C}$, the $\mathrm{pH}$ was around 4 to 5 , and the salinity was less than $0.3 \mathrm{~mol} /$ liter (1). The maximum temperature measured in the Lau Basin fluids was $400^{\circ} \mathrm{C}$, the $\mathrm{pH}$ was around 2 , and there was a high concentration of heavy metals $(20)$

A total of 20 hyperthermophilic strains were isolated from the North Fiji Basin samples (17). Another isolate was obtained from a sample prepared by scraping (under anaerobic conditions) the external surface of a gastropod (Alviniconcha hessleri) shell collected in the Lau Basin and transferred into and rinsed with degassed seawater. The resulting scrapings were inoculated into SME medium (47) and processed like the other samples. One of the North Fiji Basin isolates, strain GE5, has been described previously as the type strain of Pyrococcus abyssi (17) and was used in this study as a reference strain. The isolates and reference strains used in this study are listed in Table 1.

Pyrococcus furiosus DSM 3638, Pyrococcus woesei DSM 3773, Thermococcus stetteri DSM 5262, Thermococcus litoralis DSM 5474, and Thermococcus celer DSM 2476 were obtained from the Deutsche Sammlung von Mikroorganismen (DSM), Braunschweig-Stökheim, Germany. Pyrococcus abyssi $\mathrm{GE}^{\mathrm{T}}(\mathrm{T}=$ type strain) was obtained from our laboratory in Roscoff, France, Pyrococcus sp. strain GB-D was kindly provided by Carl O. Wirsen, Woods Hole Oceanographic Institution, Woods Hole, Mass., and Pyrococcus sp. strain AL-2 was kindly provided by Anna-Louise Reysenbach, University of Indiana, Bloomington.

Culture conditions. Isolates and reference strains were cultured in standard YPS medium (17). Briefly, 1 liter of YPS medium contained artificial seawater (23.4 g of NaCl, $10.8 \mathrm{~g}$ of $\mathrm{MgCl}_{2} \cdot 6 \mathrm{H}_{2} \mathrm{O}, 4.0 \mathrm{~g}$ of $\mathrm{Na}_{2} \mathrm{SO}_{4}, 0.7 \mathrm{~g}$ of $\mathrm{KCl}, 0.2 \mathrm{~g}$ of $\mathrm{NaHCO}_{3}, 0.09 \mathrm{~g}$ of $\mathrm{KBr}, 0.025 \mathrm{~g}$ of $\mathrm{SrCl}_{2} \cdot 6 \mathrm{H}_{2} \mathrm{O}, 0.025 \mathrm{~g}$ of $\mathrm{H}_{3} \mathrm{BO}_{3}, 0.003 \mathrm{~g}$ of $\mathrm{NaF}$ ), $0.2 \mathrm{~g}$ of $\mathrm{CaCl}_{2}, 3.0 \mathrm{~g}$ of piperazine- $N, N^{\prime}$-bis(ethanesulfonic acid) disodium salt (PIPES buffer; Sigma Chemical Co., St. Louis, Mo.), $4 \mathrm{~g}$ of Bacto Yeast Extract (Difco), and $0.4 \mathrm{~g}$ of Bacto Peptone (Difco). The $\mathrm{pH}$ was adjusted to 6.8, resazurin $\left(1 \mathrm{mg} \mathrm{liter}^{-1}\right)$ was added, and the medium was autoclaved for $20 \mathrm{~min}$. 


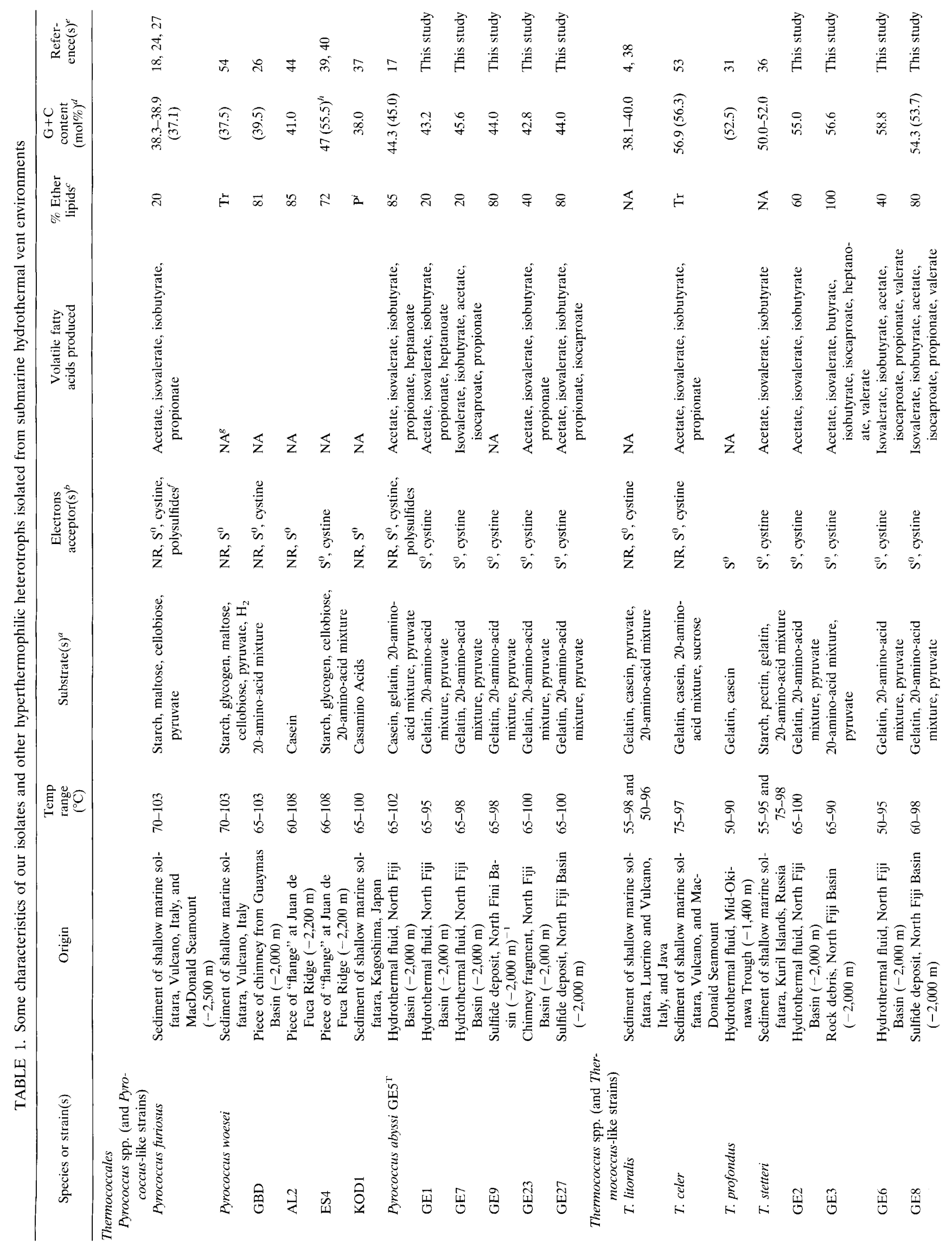




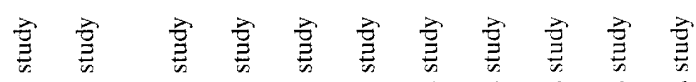

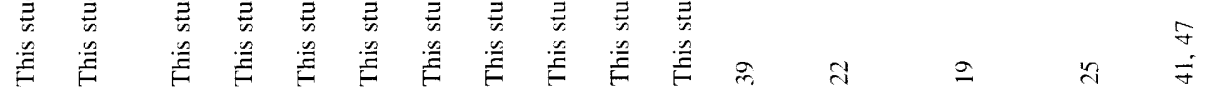

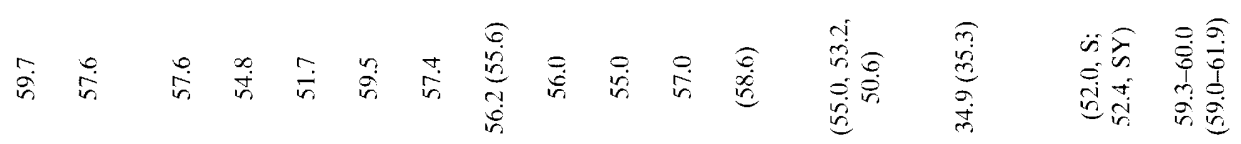

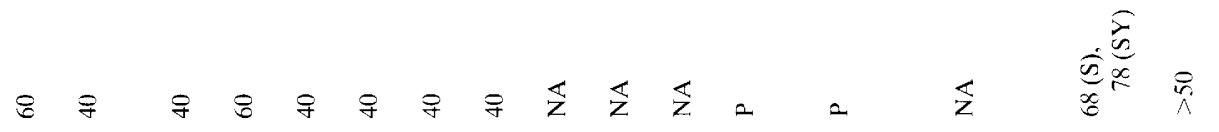

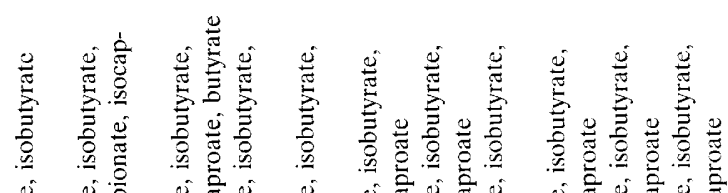

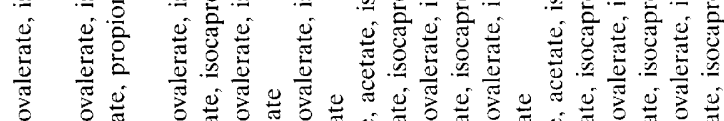

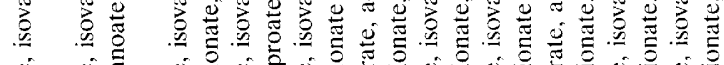

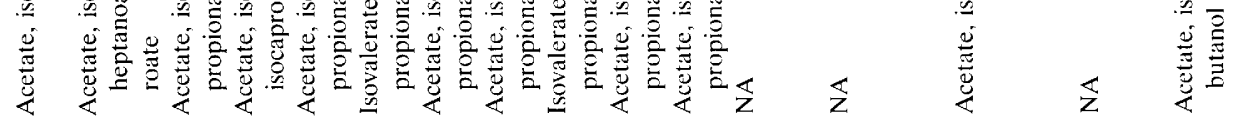

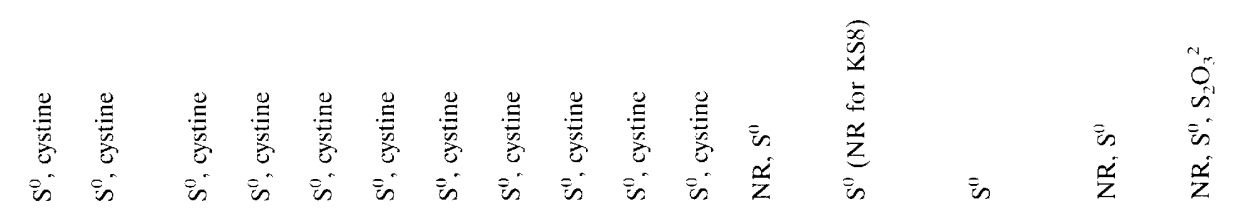
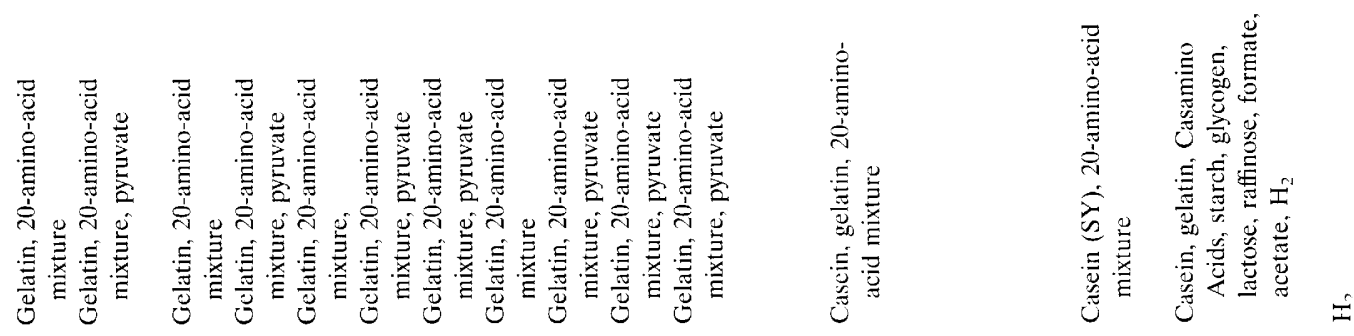

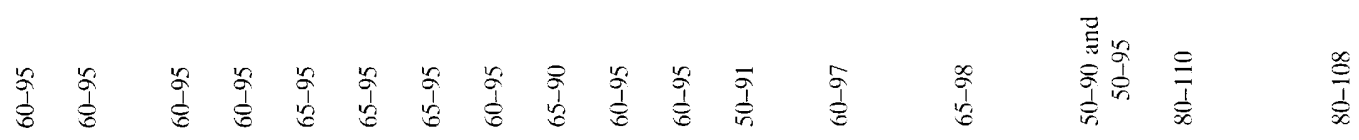

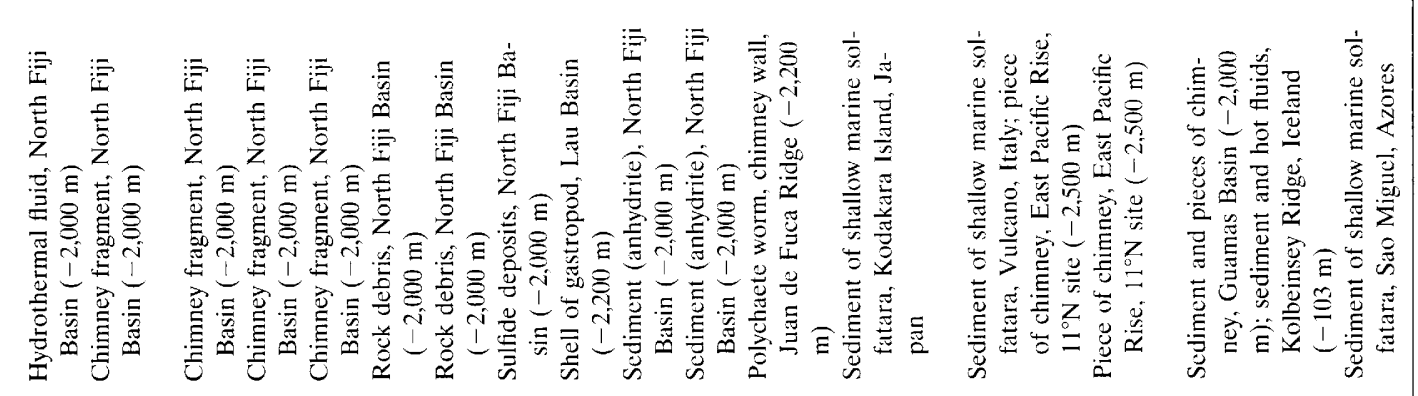

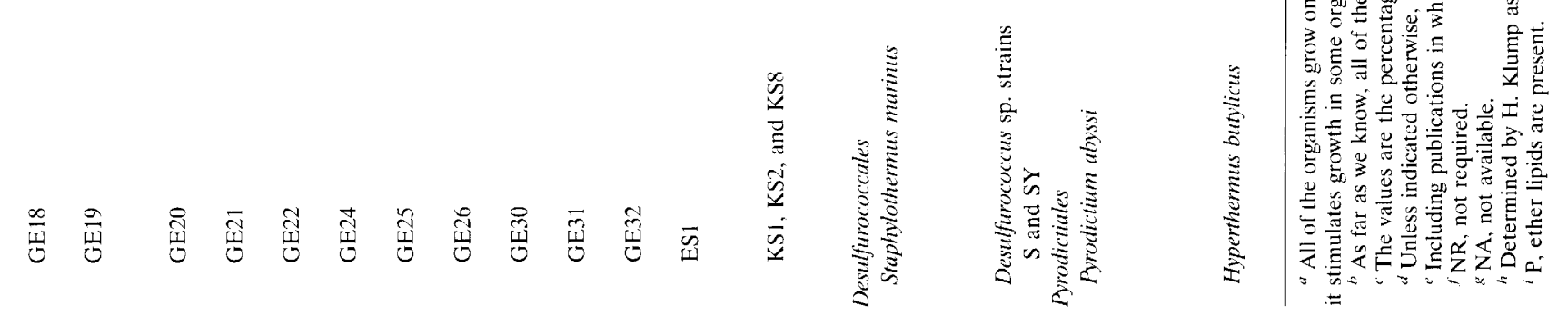


The following solutions, which had been sterilized by filtration, were then added: $10 \mathrm{ml}$ of a trace element solution (3), $1 \mathrm{ml}$ of a $10 \mathrm{mM} \mathrm{Na}_{2} \mathrm{WO}_{4}$ solution, $1 \mathrm{ml}$ of a $25 \mathrm{mM} \mathrm{FeCl}$ solution, $10 \mathrm{ml}$ of a $7 \%$ (wt/vol) $\mathrm{KH}_{2} \mathrm{PO}_{4}$ solution, and $10 \mathrm{ml}$ of a $14 \%(\mathrm{wt} / \mathrm{vol}) \mathrm{NH}_{4} \mathrm{Cl}$ solution. The medium was then completed by adding $0.5 \%(\mathrm{wt} / \mathrm{vol})$ sulfur that had been sterilized by steaming at $100^{\circ} \mathrm{C}$ for $1 \mathrm{~h}$ on 3 successive days. Anaerobiosis was achieved by applying a vacuum to the medium and saturating it with $\mathrm{N}_{2}$ (2). Finally, the medium was reduced by adding a sterile solution of $\mathrm{Na}_{2} \mathrm{~S} \cdot 9 \mathrm{H}_{2} \mathrm{O}$ (final concentration, $0.025 \%$ [wt/vol]). Cell biomass samples for protein, DNA, and lipid analyses were obtained from late-log-phase cultures grown at $85^{\circ} \mathrm{C}$ in $500-\mathrm{ml}$ serum bottles containing $200 \mathrm{ml}$ of medium and incubated in a rotary shaker water bath $(200 \mathrm{rpm}$; Bioblock, Illkirch, France) filled with dimethyl silicon oil (Prolabo, Paris, France). Plates containing YPS medium solidified with Gelrite (Sigma) (16) were incubated for 3 to 7 days a $85^{\circ} \mathrm{C}$ in anaerobic jars (Don Whitley Scientific, Ltd., Shipley, Yorkshire, England) containing an $\mathrm{N}_{2}-\mathrm{H}_{2}-\mathrm{CO}_{2}(90: 5: 5)$ gas phase $(100 \mathrm{kPa})$

Nutritional requirements and temperature range. The experiments to determine nutritional requirements and temperature ranges were performed in $27-\mathrm{m}$ Hungate culture tubes (Bellco, Vineland, N.J.) containing $10 \mathrm{ml}$ of medium and $\mathrm{N}_{2}(100 \mathrm{kPa})$ in the headspace unless indicated otherwise. Temperature ranges for growth were determined by incubating culture tubes in thermoregulated heating modules (Bioblock) whose wells were filled with dimethyl silicon oil in order to facilitate heat transfer.

The ability of the isolates to use single carbon sources for growth was determined on YPS medium without yeast extract and peptone. This mineral medium was supplemented with each carbon source (starch, gelatin, maltose, yeast extract, peptone, tryptone, pyruvate, casein hydrolysate, and beef extract) at a fina concentration of $0.2 \%(\mathrm{wt} / \mathrm{vol})$ and a filter-sterilized solution of vitamins (10 $\mathrm{ml} /$ liter) (3). A mixture of 20 amino acids, each at a concentration of $0.1 \mathrm{mM}$, was also tested. Each tube was inoculated with $100 \mu$ l of an exponentially growing culture (final concentration, ca. $10^{6}$ cells per $\mathrm{ml}$ ) and incubated at $85^{\circ} \mathrm{C}$. All tests were performed in duplicate, and a control in which no carbon substrate was added was used as a baseline since some growth due to nutrients added with the inoculum was expected.

The possible electron acceptors $\mathrm{L}-(-)$-cystine, $\mathrm{SO}_{3}{ }^{2-}, \mathrm{SO}_{4}{ }^{2-}, \mathrm{S}_{2} \mathrm{O}_{3}{ }^{2-}$, and $\mathrm{Fe}_{3}{ }^{+}$were each tested at a final concentration of $30 \mathrm{mM}$ in YPS medium withou sulfur and $\mathrm{Na}_{2} \mathrm{SO}_{4}$ under the conditions described above for carbon sources; 1 $\mathrm{mM} \mathrm{Ti}(\mathrm{III})$ citrate was used as the reducing agent in place of $\mathrm{Na}_{2} \mathrm{~S} \cdot 9 \mathrm{H}_{2} \mathrm{O}$ in these experiments. A control in which no electron acceptor was added was used a baseline since growth due to fermentation was expected. Sulfur was added along with each electron acceptor as a control for possible growth inhibition by the substrates. Pyrococcus abyssi, Pyrococcus furiosus, T. litoralis, and T. stetter were used as reference organisms in the growth tests.

Growth was monitored by measuring $\mathrm{H}_{2} \mathrm{~S}$ production as described by CordRuwisch (11). The final cell density, which was reached after 1 to 7 days of incubation (depending on the isolate), was estimated by direct cell counting (see below)

Light microscopy. Cells were observed with an Olympus model $\mathrm{BH} 2$ light microscope equipped with a phase-contrast oil immersion objective (magnification, $\times 100)$ and were counted by using a Petroff-Hausser chamber (depth, 0.02 $\mathrm{mm}$ ). To determine motility, glass slides were heated to $95^{\circ} \mathrm{C}$ immediately before observation.

Analysis of metabolic products. Volatile fatty acids were analyzed by using acidified cultures samples (final $\mathrm{HCl}$ concentration, $1 \mathrm{M}$ ) and a model 5300 gas chromatograph (Carlo Erba, Rodano, Italy) equipped with a flame ionization detector and a Carbowax $20 \mathrm{M}$ column (Supelco, Inc., Bellefonte, Pa.); the air pressure was $120 \mathrm{kPa}$, the carrier gas was $\mathrm{H}_{2}(40 \mathrm{kPa})$, the combustion gas was $\mathrm{H}_{2}(80 \mathrm{kPa})$, the oven temperature was programmed to increase from 80 to $200^{\circ} \mathrm{C}$ at a rate of $3^{\circ} \mathrm{C} / \mathrm{min}$, the detector temperature was $120^{\circ} \mathrm{C}$, and the injector temperature was $150^{\circ} \mathrm{C}$. The limit of detection for the volatile fatty acids produced in the culture medium was around $0.05 \mathrm{mM}$.

Exoprotease activity. Exoprotease activity was tested at $85^{\circ} \mathrm{C}$ by using azoca sein as the substrate. After $1 \mathrm{ml}$ of a culture in the late log phase was centrifuged for $5 \mathrm{~min}$ at $17,700 \times \mathrm{g}, 0.1 \mathrm{ml}$ of the supernatant was mixed with $0.5 \mathrm{ml}$ of a $2 \%$ (wt/vol) azocasein (Sigma) solution and $0.4 \mathrm{ml}$ of $0.1 \mathrm{M}$ phosphate buffer $\left(\mathrm{NaH}_{2} \mathrm{PO}_{4}, \mathrm{Na}_{2} \mathrm{HPO}_{4} \cdot 2 \mathrm{H}_{2} \mathrm{O}\right.$; Sigma), pH 7.2. After 60 min the reaction was stopped by adding $1 \mathrm{ml}$ of $10 \%$ (wt/vol) trichloroacetic acid, and the solution was incubated at room temperature for $30 \mathrm{~min}$. The solution was then centrifuged for $5 \mathrm{~min}$ at $19,000 \times \mathrm{g}$, and $1 \mathrm{ml}$ of the supernatant was mixed with $1 \mathrm{ml}$ of $1 \mathrm{~N}$ $\mathrm{NaOH}$. The optical density at $450 \mathrm{~nm}$ of each solution was determined with a Uvikon 930 spectrophotometer. Uninoculated medium was used as the control.

Lipid analysis. Lyophilized cell material was extracted by the method of Bligh and Dyer (5) as modified by White et al. (49). The lipids were analyzed by the method of Ross et al. (45).

Cellular protein extraction and PAGE. Cell pellets were washed twice with artificial seawater, suspended in $50 \mathrm{mM}$ Tris- $\mathrm{HCl}$ buffer $(\mathrm{pH} \mathrm{8.0)}$ containing 1 $\mathrm{mM}$ dithiothreitol, $1 \mathrm{mM}$ ethylene glycol-bis( $\beta$-aminoethyl ether)- $N, N, N^{\prime}, N^{\prime}$ tetraacetic acid (EGTA), $1 \mathrm{mM}$ EDTA, and $0.4 \mathrm{mM}$ phenylmethylsulfonyl fluoride, and disrupted by sonication in the presence of glass beads (diameter, 1 $\mathrm{mm}$ ). After centrifugation at $19,000 \times g$ and $4^{\circ} \mathrm{C}$ for $20 \mathrm{~min}$, the supernatant was centrifuged twice for $40 \mathrm{~min}$ at $19,000 \times \mathrm{g}$ and $4^{\circ} \mathrm{C}$ before we performed a sodium dodecyl sulfate (SDS)-polyacrylamide gel electrophoresis (PAGE) analysis as described by Laemmli (31). Equal amounts of protein (protein concen- trations were estimated by the Bradford method [8] by using a Bio-Rad assay kit [Bio-Rad Laboratories, Richmond, Calif.]) from all samples were loaded onto $10 \%$ polyacrylamide gels (5\% stacking gels) along with the following molecular weight standards: rabbit muscle phosphorylase $\beta$ (molecular weight, 97,400), bovine serum albumin $(66,200)$, hen egg white ovalbumin $(42,699)$, bovine carbonic anhydrase $(32,000)$, soybean trypsin inhibitor $(21,500)$, and hen egg white lysozyme $(14,400)$. The gels were stained with Coomassie brilliant blue R250.

DNA isolation and base composition. DNA was extracted as described by Charbonnier et al. (10) with the following modifications. After phenol-chloroform extraction, the DNA was precipitated by adding 0.8 volume of isopropanol, spooled onto a glass rod, washed twice with cold $70 \%$ (vol $/ \mathrm{vol})$ ethanol, and allowed to air dry. The DNA recovered was then dissolved in TE buffer $(10 \mathrm{mM}$ Tris- $\mathrm{HCl}, 1 \mathrm{mM}$ EDTA; $\mathrm{pH} 8.0$ ) and treated with $50 \mu \mathrm{g}$ of RNase A (Sigma) per $\mathrm{ml}$ for $2 \mathrm{~h}$ at $37^{\circ} \mathrm{C}$, and this was followed by phenol-chloroform extraction, spooling, and dissolution in TE buffer as described above. The DNA preparations from all strains were dialyzed together overnight at $4^{\circ} \mathrm{C}$ against two changes of 2 liters of TE buffer. The purity of each DNA preparation was such that the $A_{260} / A_{280}$ and $A_{260} / A_{230}$ ratios were consistently 1.8 to 1.9 and 2.0 to 2.3 , respectively. The DNA preparations were electrophoresed on $0.8 \%$ agarose minigels to test for impurities and degradation and always formed well-defined bands at approximately 22 to $25 \mathrm{~kb}$

The $\mathrm{G}+\mathrm{C}$ content of the DNA of each isolate was determined from its melting point in TE buffer as described by Mandel and Marmur (33) and Marmur and Doty (34). A calibration curve was obtained by using Clostridium perfringens DNA (31.0 mol\% G+C), Escherichia coli DNA (51.3 mol\% G+C), and Micrococcus lysodeikticus DNA $(72.0 \mathrm{~mol} \% \mathrm{G}+\mathrm{C})$ (all obtained from Sigma) as standards. A direct nucleotide analysis of isolates GE8, GE26, GE30, and GE31 was also performed by high-performance liquid chromatography (HPLC) after the DNAs were digested with nuclease $P 1$ as described by Zillig et al. (57) and Mesbah et al. (35); calf thymus DNA ( $42 \mathrm{~mol} \% \mathrm{G}+\mathrm{C}$; Sigma) and phage $\lambda$ DNA (48.9 mol\% G+C; Boehringer Biochemica, Mannheim, Germany) were used as the standards in this analysis.

DNA-DNA hybridization. Levels of genetic relatedness were determined by performing DNA-DNA slot blot hybridization experiments $(6,29)$. Duplicate aliquots containing 100 and $200 \mathrm{ng}$ of each genomic DNA were denatured by boiling them for $10 \mathrm{~min}$ in $0.4 \mathrm{M} \mathrm{NaOH}$ and were transferred onto positively charged membranes (Zeta-Probe; Bio-Rad) by using a slot blot apparatus (BioRad). Each membrane contained DNA from the bacterium Alteromonas carraghenovora ( 45 mol\% $\mathrm{G}+\mathrm{C}$; kindly provided by Tristan Barbeyron, Roscoff, France) as a negative control. Prehybridization for $2 \mathrm{~h}$ and hybridization were performed at the optimal temperature (28) in buffer containing $4 \times \mathrm{SSC}(1 \times$ is $0.15 \mathrm{M} \mathrm{NaCl}$ plus $0.015 \mathrm{M}$ sodium citrate), $0.5 \%$ blocking reagent (Amersham International, Les Ulis, France), $5 \%$ dextran sulfate, $100 \mu \mathrm{g}$ of denatured and sheared salmon sperm DNA per $\mathrm{ml}$, and $20 \%$ deionized formamide. Probes (DNAs that were sheared by sonication to lengths of 500 to $2,000 \mathrm{bp}$ and were heat denatured) were labelled by using an ECL random prime labelling kit (Amersham International) and were added $(10 \mathrm{ng} / \mathrm{ml})$ to the prehybridized membranes in hybridization buffer, and the preparations were incubated overnight $(16 \mathrm{~h})$. Hybridized membranes were washed twice at $65^{\circ} \mathrm{C}(15 \mathrm{~min}$ each $)$ successively in $1 \times \mathrm{SSC}-0.1 \%$ SDS, $0.5 \times \mathrm{SSC}-0.1 \%$ SDS, and $0.1 \times \mathrm{SSC}-0.1 \%$ SDS. Chemiluminescence was detected with an ECL detection kit as recommended by the manufacturer (Amersham). The membranes were exposed to Hyperfilm (Amersham) for 10 to $20 \mathrm{~min}$ at room temperature. Separate tests involving self-hybridization of strain GE5 ${ }^{\mathrm{T}}$ DNA revealed that there was a linear response between the amount of target DNA and the signal intensity under the exposure conditions used (data not shown). As the labelling efficiency varied a little from one probe DNA to another, the exposure time was adjusted to ensure that the intensities of the signals for 100 and $200 \mathrm{ng}$ remained within the linear part of the response curve. The intensities of the signals were measured with a densitometer (Vernon, Paris, France). To reprobe the blots, the probes were removed from the membranes by using the following protocol: after washing for $5 \mathrm{~min}$ in $5 \times \mathrm{SSC}$ at room temperature, the membranes were stripped of the probe by incubating them for $2 \mathrm{~min}$ in $0.1 \% \operatorname{SDS}$ at $95^{\circ} \mathrm{C}$. We found that the same membrane could be stripped and reprobed at least five times with no detectable loss of sensitivity. The signal (maximum peak area) produced by self-hybridization of the probe with homologous target DNA was defined as $100 \%$, and the final percentage of similarity for each pair of strains was the average of the values calculated for the duplicate slots containing 100 and $200 \mathrm{ng}$ of target DNA. The complete similarity matrix $(20$ by 20$)$ was converted to a distance matrix with the transformed elements equal to 1 - (percentage of similarity $/ 100$ ) and then used for a cluster analysis by the unweighted pair group method of analysis program from the PHYLIP package (version 3.4) included in the GCG software package version 8.0) (Genetic Computer Group, University of Wisconsin Biotechnology, Madison, Wis.)

\section{RESULTS}

Morphology. The cells of all of the isolates were regular to irregular cocci that were 0.8 to $2 \mu \mathrm{m}$ in diameter. Motility was observed with seven isolates (GE1, GE3, GE7, GE23, GE19, GE20, and GE27). All strains grew on Gelrite plates at $85^{\circ} \mathrm{C}$ 
TABLE 2. Nutritional requirements of the isolates

\begin{tabular}{|c|c|c|c|c|c|c|c|c|c|}
\hline \multirow[b]{2}{*}{ Strain or species } & \multicolumn{9}{|c|}{ Growth in the presence of the following substrate ${ }^{a}$ : } \\
\hline & 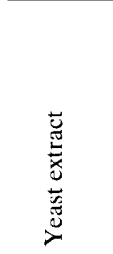 & $\begin{array}{l}0 \\
0 \\
0 \\
0\end{array}$ & 号 & 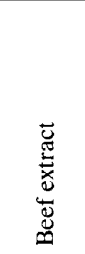 & 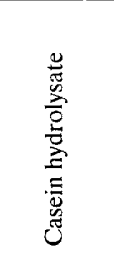 & $\frac{\text { 总 }}{0}$ & 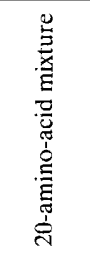 & 苞 & 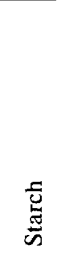 \\
\hline GE1 & $+t+$ & $++t$ & +++ & ++ & ++++ & $++t$ & ++ & + & - \\
\hline GE2 & $++t$ & +++ & +++ & ++ & ++++ & ++++ & ++ & + & - \\
\hline GE3 & ++++ & - & + & ++ & +++ & $(+)$ & $(+)$ & + & - \\
\hline $\mathrm{GE} 5^{\mathrm{T}}$ & $++t$ & +++ & ++++ & +++ & $+++t$ & $+t+$ & ++ & + & - \\
\hline GE6 & +++ & +++ & +++ & ++ & ++++ & +++ & + & + & - \\
\hline GE7 & ++++ & +++ & ++++ & ++ & ++++ & +++ & ++ & + & - \\
\hline GE8 & +++ & +++ & ++++ & ++ & ++++ & +++ & + & + & - \\
\hline GE9 & ++++ & +++ & +++ & ++ & ++++ & +++ & ++ & + & - \\
\hline GE18 & +++ & ++ & + & ++ & ++++ & + & ++ & - & - \\
\hline GE19 & $++t$ & ++ & + & - & ++++ & $(+)$ & + & + & - \\
\hline GE20 & ++++ & ++ & $(+)$ & $(+)$ & ++ & $(+)$ & + & - & - \\
\hline GE21 & +++ & +++ & + & $+t$ & ++++ & + & ++ & + & - \\
\hline GE22 & +++ & +++ & +++ & ++ & ++++ & ++++ & $(+)$ & - & - \\
\hline GE23 & +++ & +++ & ++++ & +++ & ++++ & ++ & ++ & + & - \\
\hline GE24 & ++++ & +++ & - & ++ & ++++ & $(+)$ & +++ & + & - \\
\hline GE25 & +++ & +++ & + & ++ & +++ & $(+)$ & $(+)$ & + & - \\
\hline GE26 & +++ & $++t$ & + & ++ & ++++ & ++ & ++ & - & - \\
\hline GE27 & +++ & +++ & ++ & ++ & ++++ & $(+)$ & + & + & - \\
\hline GE30 & +++ & ++ & + & ++ & ++ & + & $(+)$ & + & - \\
\hline GE31 & ++++ & +++ & + & ++ & ++++ & + & ++ & + & - \\
\hline GE32 & +++ & +++ & $+t$ & $+t+$ & ++++ & + & ++ & + & - \\
\hline Pyrococcus furiosus & +++ & +++ & +++ & +++ & +++ & +++ & ++ & + & ++ \\
\hline T. litoralis & +++ & ++ & + & ++ & +++ & +++ & ++ & + & ++ \\
\hline T. stetteri & ++++ & +++ & + & +++ & ++++ & +++ & ++ & - & ++ \\
\hline
\end{tabular}

${ }^{a}$ Growth was measured by determining the final cell density and was expressed as follows: - , no growth; $(+), 5 \times 10^{6}$ to $10^{7}$ cells per ml;,$+ 10^{7}$ to $5 \times 10^{7}$ cells per $\mathrm{ml} ;++, 5 \times 10^{7}$ to $10^{8}$ cells per ml;,$+++ 10^{8}$ to $2 \times 10^{8}$ cells per ml;,$++++>2 \times 10^{8}$ cells per ml. The concentration of each proteinaceous substrate tested was $0.2 \%$ (wt/vol), and pyruvate, maltose, and starch were each added at a concentration of $0.5 \%$ (wt/vol). The concentration of each of the amino acids in the 20 -amino-acid mixture was $0.1 \mathrm{mM}$. All of the isolates and the references strains grew very well $(+++$ to ++++$)$ in YPS medium; none of them except Pyrococcus furiosus grew on maltose.

and had similar colonial morphologies; the colonies were white or cream, convex, and 0.5 to $2.0 \mathrm{~mm}$ in diameter.

Nutritional requirements. The isolates did not grow autolithotrophically in mineral medium containing elemental sulfur and $\mathrm{CO}_{2}$ but grew well heterotrophically and anaerobically in the presence of $S^{0}$. The nutritional requirements of the isolates were very similar. Most of the isolates grew very well on complex proteinaceous substrates (yeast extract, peptone, tryptone, beef extract, and casein hydrolysate) and proteins (gelatin); however, there were a few exceptions (Table 2). For instance, isolate GE3 did not grow on peptone and grew poorly on gelatin; isolate GE19 did not grow on beef extract and grew poorly on gelatin; isolate GE20 grew poorly on tryptone, beef extract, and gelatin; and isolate GE24 did not grow on tryptone and grew poorly on gelatin. All of the isolates were able to use a mixture of the 20 natural amino acids as a sole carbon and energy source, although the growth was generally weaker than the growth observed with complex substrates, especially for strains GE3, GE22, GE25, and GE30. No growth was observed on carbohydrates (starch and maltose). Most of the isolates grew poorly on pyruvate; the exceptions were isolates GE18, GE20, GE22, and GE26, which did not grow at all on this substrate.

None of the isolates was able to use any of the electron acceptors tested except $S^{0}$ and $\mathrm{L}-(-)$-cystine. Therefore, they appeared to be sulfur dependent.
Temperature ranges. The maximum growth temperatures (Table 1) for all isolates were between 90 and $101^{\circ} \mathrm{C}$. The most thermophilic isolates grew at temperatures ranging from 60 to $98^{\circ} \mathrm{C}$ (GE8) or from 65 to $101^{\circ} \mathrm{C}$ (GE2, GE7, GE9, GE23, and GE27). The less thermophilic isolates (GE3 and GE30) grew at temperatures between 65 and $90^{\circ} \mathrm{C}$. All of the other isolates grew at temperatures up to $95^{\circ} \mathrm{C}$, and the minimum growth temperature was $65^{\circ} \mathrm{C}$ (GE1, GE22, GE24, and GE25), $60^{\circ} \mathrm{C}$ (GE18, GE19, GE20, GE21, GE26, GE31, and GE32), or 50 $\mathrm{C}$ (GE6).

Fermentation products. When grown on YPS medium, all of the isolates produced acetate, isovalerate, isobutyrate, and propionate (Table 1). About 3 to $8 \mu \mathrm{mol}$ of acetate and isovalerate per $\mathrm{ml}, 1$ to $2 \mu \mathrm{mol}$ of isobutyrate per $\mathrm{ml}$, and up to $0.2 \mu \mathrm{mol}$ of propionate per $\mathrm{ml}$ were produced in $20 \mathrm{~h}$. The relative proportions of these products depended on the isolate. Butyrate was produced only by GE3 and GE20 (about 2 and $0.5 \mu \mathrm{mol} \mathrm{ml} \mathrm{m}^{-1}$ ), and caproate was detected only in GE3. Other volatile fatty acids were also detected in some isolates but usually at very low concentrations $\left(<0.1 \mu \mathrm{mol} \mathrm{ml}^{-1}\right)$. In all of the isolates, growth was accompanied by exponential $\mathrm{H}_{2} \mathrm{~S}$ production which paralleled growth. The $\mathrm{H}_{2} \mathrm{~S}$ concentration reached up to $13 \mu \mathrm{mol} \mathrm{ml}{ }^{-1}$ when cells entered the stationary phase (data not shown).

Exoprotease activity. Exoprotease activity was detected in three isolates, GE8, GE19, and GE22. GE8 and GE19 exhib- 


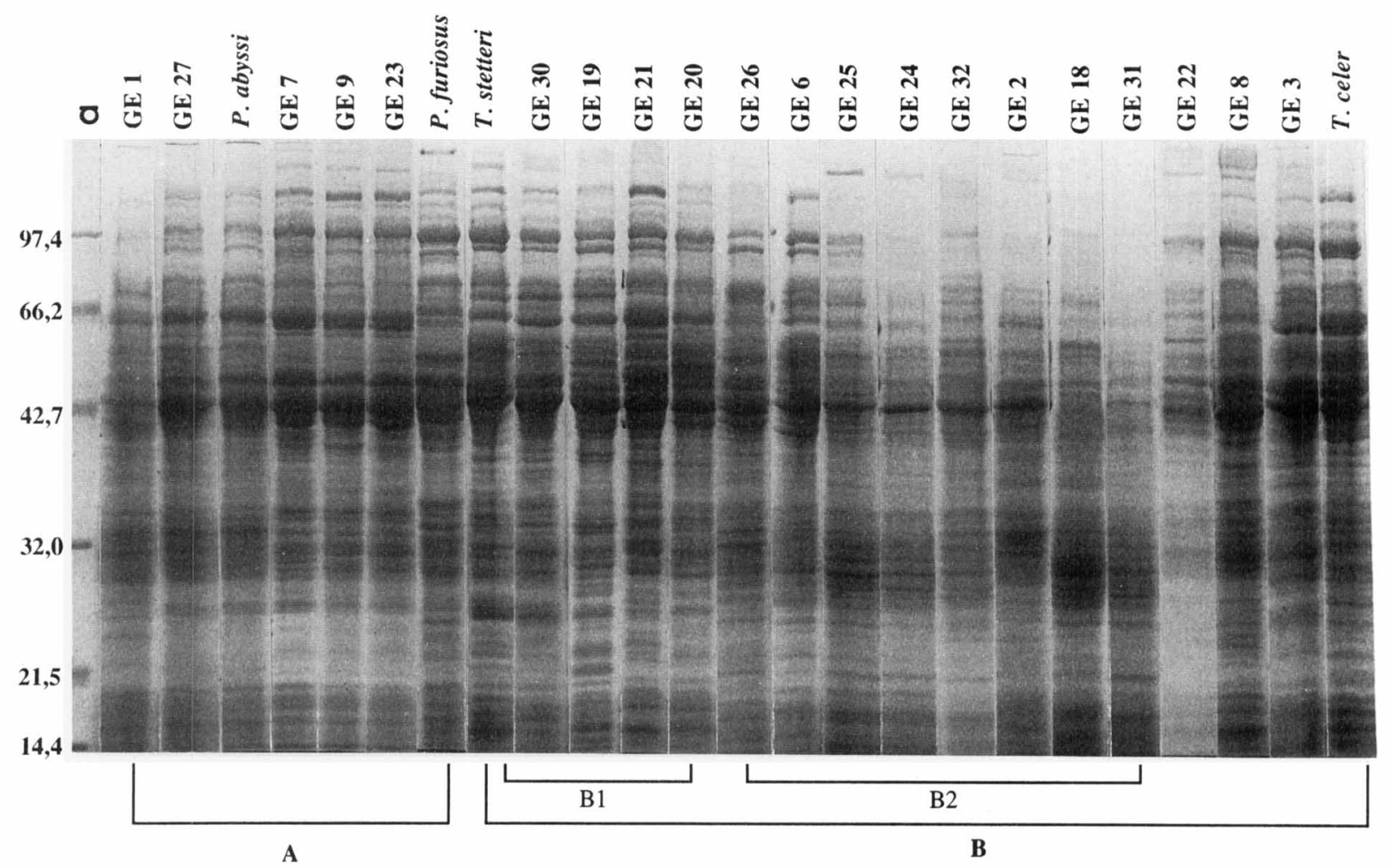

FIG. 1. Electrophoretic analysis of cellular protein extracts of the isolates and four reference strains. Samples were electrophoresed on a $10 \%$ polyacrylamide gel that was stained with Coomassie brilliant blue. Lane a contained molecular weight markers, whose sizes (in kilodaltons) are indicated on the left. Clusters A, B, B1, and $\mathrm{B} 2$ are the electrophoresis protein profile groups described in the text.

ited levels of proteinase activity similar to the levels observed in $T$. stetteri, but the level of activity in GE22 was almost twofold higher.

Lipid composition. Archaeal ether lipids were present in all of the isolates tested. No significant amounts of (bacterial) methyl esters were detected. Diether and tetraether forms were found in all of the isolates except GE3, which contained only traces of diether lipids (Table 1 ).

Cellular protein profiles. Different cellular protein patterns were observed (Fig. 1), and these patterns allowed us to divide the isolates into two main clusters. Cluster A strains were characterized by four bands at molecular weights of 98,000 , $90,000,55,000$, and 48,000, which were absent in cluster B strains. Cluster B strains produced three characteristic protein bands at molecular weights of 97,000,93,000, and 50,000.

Five isolates (GE1, GE7, GE9, GE23, and GE27) belonged to cluster $A$ and produced profiles that were almost identical to the Pyrococcus abyssi GE5 ${ }^{\mathrm{T}}$ profile and rather similar to the Pyrococcus furiosus profile. Identical profiles were produced by isolates GE7, GE9, and GE23 and by isolates GE5 and GE27, while GE1 produced a slightly different profile than GE27. The other isolates were classified in cluster B, which appeared to be less homogeneous than cluster A. However, two subclusters were distinguished; one of these subclusters included isolates GE19, GE20, GE21, and GE30 (subcluster B1), and the other included isolates GE2, GE6, GE18, GE24, GE25, GE26, GE31, and GE32 (subcluster B2). Three strains (GE3, GE8, and GE22) did not group with either of the subclusters. The profiles of the subcluster B1 strains were quite similar to the $T$. stetteri profile, although some bands of the subcluster B1 strains appeared to be less intense. The $T$. celer protein pattern was quite similar to the isolate GE3 pattern.
DNA base composition. The $\mathrm{G}+\mathrm{C}$ contents of the isolates varied from 43.2 to $59.7 \mathrm{~mol} \%$ (Table 1 ). Three $\mathrm{G}+\mathrm{C}$ content groups were distinguished; one group contained isolates which had $\mathrm{G}+\mathrm{C}$ contents ranging from 43 to $46 \mathrm{~mol} \%\left(\mathrm{GEl}, \mathrm{GE} 5^{\mathrm{T}}\right.$, GE7, GE9, GE23, and GE27), the second group contained isolates which had $\mathrm{G}+\mathrm{C}$ contents ranging from 51 to $54 \mathrm{~mol} \%$ (GE8 and GE22), and the third group contained isolates which had $\mathrm{G}+\mathrm{C}$ contents ranging from 55 to $60 \mathrm{~mol} \%$ (the rest of the isolates).

Levels of DNA similarity. The results of DNA-DNA hybridization experiments performed with our isolates and seven reference strains are shown in Table 3 . The hybridization experiments revealed that there were two major DNA similarity groups. One group contained isolates GE1, GE7, GE9, GE23, and GE27, which exhibited levels of similarity of at least $68 \%$ and hybridized strongly ( 65 to $100 \%$ ) with GE5, the type strain of Pyrococcus abyssi. The levels of DNA similarity with the other Pyrococcus strains were never more than 42\% (GE27 and GBD), and the levels of similarity with the three Thermococcus species were much lower (the maximum level of similarity was $21 \%$ for GE27 and T. litoralis). This group appeared to be weakly connected to the rest of the isolates (average level of similarity, $6 \%$ ).

The levels of DNA similarity between pairs of the other isolates fluctuated between 0 and $100 \%$, but most pairs (12 of 15 ) exhibited levels of DNA similarity between 60 and $100 \%$. Isolates GE2, GE6, GE18, GE19, GE20, GE21, GE24, GE25, GE26, GE30, GE31, and GE32 did not exhibit levels of similarity of more than $58 \%$ with the Pyrococcus reference strains (GE19 and GBD) or more than $42 \%$ with the Thermococcus reference strains (GE20 and T. stetteri). Isolates GE3, GE8, and GE22 did not exhibit levels of similarity of more than $28 \%$, 


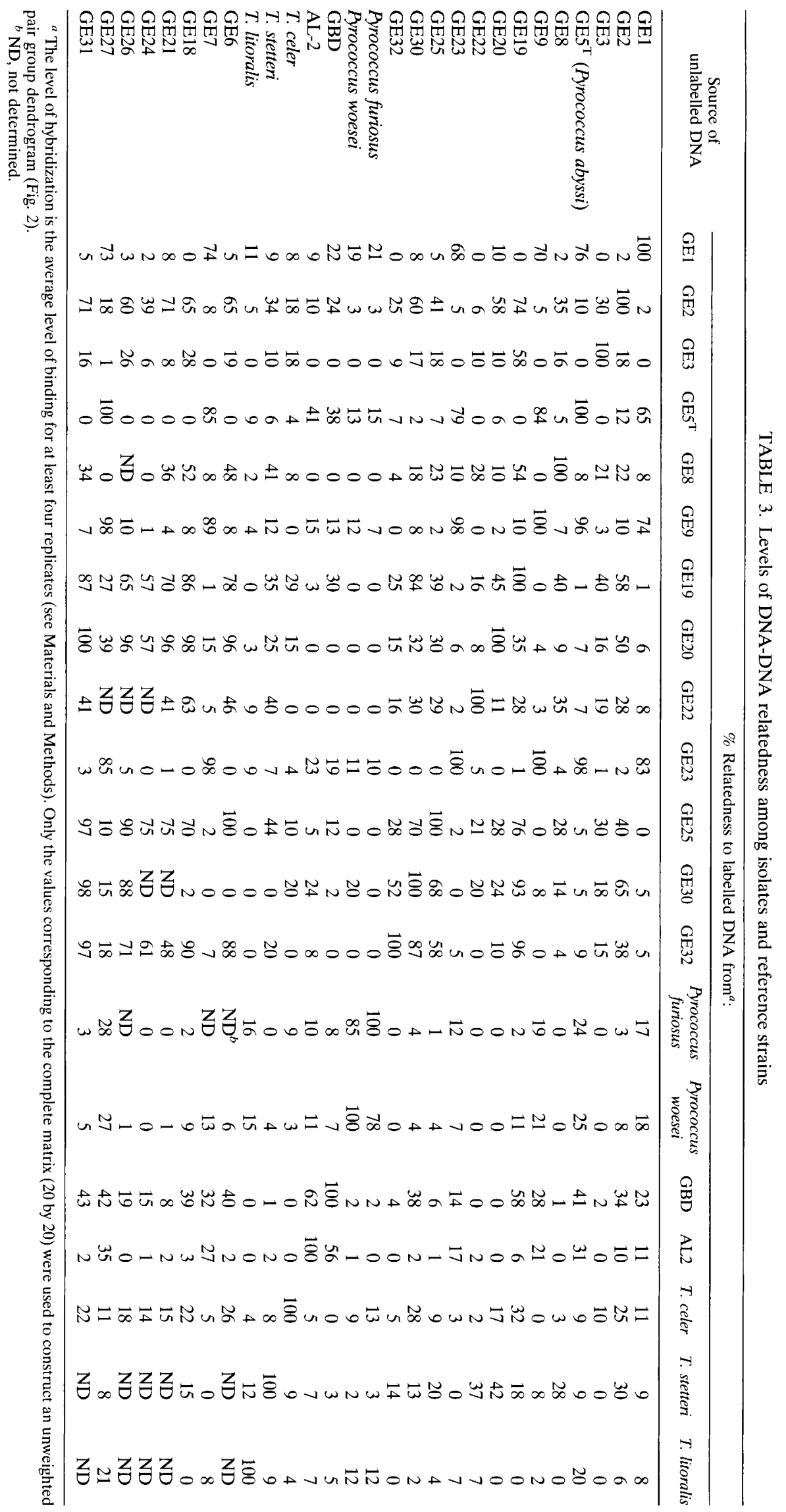



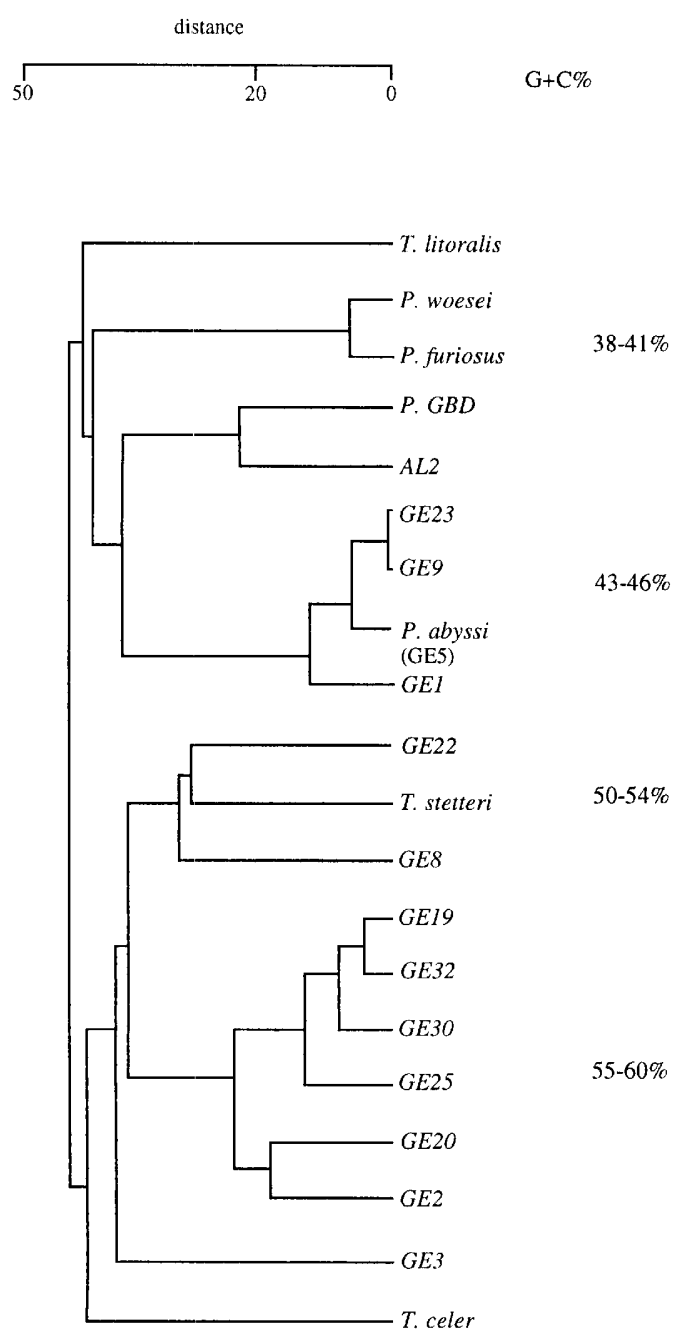

FIG. 2. Unweighted pair group dendrogram based on DNA-DNA hybridization data. We used 12 isolates and 8 reference strains for which a complete distance matrix (20) by 20 ) was obtained. A distance value of 20 on the dendrogram is equivalent to a level of hybridization homology of $60 \%$. The $\mathrm{G}+\mathrm{C}$ content ranges of the strains are represented by the boxes on the right.

and the highest levels of similarity with reference strains were $38 \%$ (GE8 and T. stetteri) and $41 \%$ (GE22 and T. stetteri).

A complete matrix ( 20 by 20 ) was derived from the DNADNA hybridization data and was used to construct a dendrogram (Fig. 2). Two main clusters were observed. One cluster contained Pyrococcus abyssi GE5 ${ }^{\mathrm{T}}$, GE1, GE9, and GE23 (GE7 and GE27 were not included in the tree construction analysis), the three Pyrococcus species (Pyrococcus furiosus, Pyrococcus woesei, and strain GBD), and strain AL2. The type strain of $T$. litoralis joined this cluster at a low level of similarity. The second cluster contained the other strains; two of these strains (GE22 and GE8) grouped with T. stetteri. T. celer appeared to differ from our isolates and joined the second cluster at a low level of similarity.

\section{DISCUSSION}

All of the isolates were coccoid, sulfur-metabolizing heterotrophs and grew at high temperatures under strictly anaerobic conditions. These characteristics corresponded to characteristics described previously for hyperthermophilic heterotrophic
Archaea. The presence of ether lipids in the membranes of our isolates allowed us to assign them to the domain Archaea (50).

The previously described heterotrophic, anaerobic, marine, hyperthermophilic archaea are represented by the genera Thermococcus (53), Pyrococcus (18), Desulfurococcus (25), Staphylothermus (19), Pyrodictium (47), and Hyperthermus (55). Our isolates share several morphological features with certain strains belonging to these genera, particularly the genera belonging to the Thermococcales (the genera Thermococcus and Pyrococcus). For instance, constricted duplex forms, which are characteristic of members of the Thermococcales (51), were observed during exponential growth of our isolates. Although this form of division can also be found in Hyperthermus strains, it is considerably less frequent in this genus than in the Thermococcales. When our strains were grown in nonagitated cultures, aggregates of cells were frequently observed. However, these clusters differed from those of Staphylothermus (19) or Hyperthermus strains (52), which form clumps containing up to 100 cells. A doubling time of less than $2 \mathrm{~h}$, as observed for our isolates, is a common characteristic of members of the Thermococcales (51). Our isolates produced the same volatile fatty acids that are found in members of the genera Thermococcus, Pyrococcus, Staphylothermus (7), and Desulfurococcus (25), but did not produce any butanol as has been observed for Hyperthermus strains (52) and Pyrodictium abyssi (41). Other phenotypic characteristics, such as motility, growth temperature range, nutritional requirements, and sulfur dependence, appeared to be too variable in the members of the six genera mentioned above to be useful for classification purposes.

It has been reported previously that T. celer (14), Pyrococcus woesei, and Thermococcus sp. strain AN1 (32) contain only diether in their membranes, whereas Desulfurococcus strains contain tetraether as a major component (14). In The Prokaryotes, 2nd ed., it was proposed that the presence of the diether lipids is a signature for the Thermococcales (51). However, Pyrococcus abyssi GE5 ${ }^{\mathrm{T}}$, which was clearly assigned to the Thermococcales (17), contains only low amounts of diether. Many of our strains had both di- and tetraethers in their membrane lipids, but the tetraethers were dominant in most of the strains. Similar lipid compositions were also found for recently described isolates assigned to the order Thermococcales (22, 37) and to the new species Thermococcus profondus (30). These observations indicate that lipid composition (ratio of diether to tetraether) is not a good criterion for classification of thermophilic, sulfur-metabolizing archaea.

The $\mathrm{G}+\mathrm{C}$ contents of our isolates ranged from $43 \%$ to 60 mol\% and could be divided into three groups ( 43 to 46,50 to 54 , and 55 to $60 \mathrm{~mol} \%$ ). The first $\mathrm{G}+\mathrm{C}$ content group corresponded to the genus Pyrococcus, whose members have $\mathrm{G}+\mathrm{C}$ contents ranging from of 38 to $45 \% \mathrm{~mol} \%$. The members of this group were the most thermophilic organisms and had the shortest doubling times, features which are typical of Pyrococcus species. These findings correlated well with the classification based on protein profiles (Fig. 1) and were further confirmed by DNA-DNA hybridization data (Table 3 ); the protein profiles of the Pyrococcus isolates were included with the group A protein profiles at a level similar to the level predicted by hybridization data. This is consistent with the findings of Cato et al. (9), who reported that strains with levels of DNA similarity greater than $80 \%$ usually produce identical protein patterns. The members of the second $\mathrm{G}+\mathrm{C}$ content group (50 to $54 \mathrm{~mol} \%$ ) could belong to the genus Desulfurococcus or the genus Thermococcus, whose members have $\mathrm{G}+\mathrm{C}$ contents ranging from 41 to 52 and 38 to $57 \mathrm{~mol} \%$, respectively. It is more likely that the members of the second $\mathrm{G}+\mathrm{C}$ content group belong to the genus Thermococcus than that they belong 
to the genus Desulfurococcus because isolates GE8 and GE22 exhibited levels of similarity of around $40 \%$ with $T$. stetteri, had similar protein profiles, and exhibited strong exoprotease activity. The $\mathrm{G}+\mathrm{C}$ contents of the members of the third $\mathrm{G}+\mathrm{C}$ content group ( 54 to $60 \mathrm{~mol} \%$ ) are similar to the $\mathrm{G}+\mathrm{C}$ content of Thermococcus strains, and these organisms have the characteristics described for this genus, but they exhibit only low levels of similarity $(<30 \%)$ with reference species.

In this study, we found that slot blot hybridization in which a nonisotopic method is used can provide reliable information about the levels of DNA-DNA relatedness of a large number of isolates as long as optimum conditions are used (see above). However, the results obtained from slot blot hybridization experiments should be considered to be only semiquantitative because of the strong influence of experimental factors (6). Nevertheless, the results obtained by this method were in good agreement with the results that we obtained previously for a smaller set of strains by using a method (S1 nuclease and radioactively labelled DNA) $(15 \mathrm{a}, 17)$ which is generally considered the most accurate method available (21).

The dendrogram in Fig. 2 is a convenient way to represent the levels of DNA relatedness among the isolates, but for the reasons cited above it should not be overinterpreted as providing quantitative evidence concerning the genetic distances between isolates. Nevertheless, some general conclusions concerning the genetic relationships among the isolates can be drawn. The level of DNA-DNA similarity for species boundaries was set arbitrarily at $60 \%$ by Johnson (27). More recently (48), a value of $70 \%$ was proposed, and this value seems to be better suited as a species boundary value for procaryotes. Even when the lower value (which equals a distance of 20 on the dendrogram) was used, several of our isolates represented new species. Our data suggest that GE8 and GE22 could represent new Thermococcus species that are closely related to T. stetteri and that the remaining isolates could be placed in three other new Thermococcus species, one containing isolates GE19, GE32, GE30, and GE25), one containing isolates GE20 and GE2, and one containing isolate GE3. This conclusion seems to be particularly true for isolate GE3, which appears to be only distantly related to all of the other strains. It is surprising that $T$. litoralis appeared to be rather close to the genus Pyrococcus on the dendrogram. Indeed, the $\mathrm{G}+\mathrm{C}$ content of $T$. litoralis $(39.1 \mathrm{~mol} \%)$ is within the range of $\mathrm{G}+\mathrm{C}$ contents for the genus Pyrococcus; reclassification has been suggested previously (51).

Assignment of our isolates to the Thermococcales is not surprising since the enrichment procedures which we used were those described for the Thermococcales. In addition, members of the Thermococcales are widely distributed in the hydrothermal systems of the planet (43). However, it is surprising how diverse the isolates belonging to the Thermococcus group were compared with the isolates belonging to the Pyrococcus group, which were quite homogeneous. Our tentative identification of five novel Thermococcus species for 15 isolates that seemed to be almost identical after phenotypic and physiological studies clearly shows the need for genomic studies of the heterotrophic sulfur-metabolizing coccoid hyperthermophiles.

\section{ACKNOWLEDGMENTS}

We thank Daniel Desbruyères and Suguru Ohta, co-chief scientists of the Starmer and Biolau cruises organized by IFREMER and JAM STEC, for inviting one of us to participate in the Starmer cruise and for providing samples. Marc Vernet and Marc Gellé are gratefully acknowledged for technical assistance. We thank Jacques Dussauze for gas analysis, Claude Leroux and Olivier Collin for help with the com- puter analysis, Jacques Orillon for professional photographic work, and Lee Vogel for help in revising the English.

Viggó Thór Marteinsson was supported by a Franco-Islandais fellowship (Programme Franco-Islandais). This work was supported by CNRS and IFREMER and by grants from the SN Elf Aquitaine.

\section{REFERENCES}

1. Auzende, J. M., T. Urabe, C. Deplus, J. P. Eissen, D. Grimaud, P. Huchon, J. Ishibashi, Y. Iwaabuchi, P. Jarvis, M. Joshima, K. Kisimoto, Y. Kuwahara, Y. Lafoy, T. Matsumoto, J. P. Mazé, K. Mitsuzawa, H. Monma, T. Nafanuma, Y. Nojiri, S. Otha, K. Otsuka, Y. Okuda, H. Ondreas, A. Otsuki, E. Ruellan, M. Sibuet, M. Tanahashi, T. Tanaka, and T. Urabe. 1990. Active spreading and hydrothermalism in North Fiji Basin (SW Pacific). Results of Japanese French cruise Kaiyo 87. Mar. Geophys. Res. 12:269-283.

2. Balch, W., and R. S. Wolfe. 1976. New approach to the cultivation of methanogenic bacteria: 2-mercaptoethanesulfonic acid (HS-CoM)-dependent growth of Methanobacterium ruminantium in a pressurized atmosphere. Appl. Environ. Microbiol. 32:781-791.

3. Balch, W. E., G. E. Fox, L. S. Magrum, C. R. Woese, and R. S. Wolfe. 1979 Methanogens: reevaluation of a unique biological group. Microbiol. Rev. 43:260-296.

4. Belkin, S., and H. W. Jannasch. 1985. A new extremely thermophilic sulfurreducing heterotrophic bacterium. Arch. Microbiol. 141:181-186.

5. Bligh, E. G., and W. J. Dyer. 1959. A rapid method of total lipids extraction and purification. Can. J. Biochem. Physiol. 35:911-917.

6. Boivin, M. F., V. L. Morris, E. C. M. Lee-Chan, and R. G. E. Murray. 1985. Deoxyribonucleic acid relatedness between selected members of the genus Aquaspirillum by slot blot hybridization: Aquaspirillum serpens (Mueller 1786) Hylemon, Wells, Krieg, and Jannasch 1973 emended to include Aquaspirillum bengal as a subjective synonym. Int. J. Syst. Bacteriol. 35:512517.

7. Bonch-Osmolovskaya, E. A., and K. O. Stetter. 1991. Interspecies hydrogen transfer in cocultures of thermophilic archaea. Syst. Appl. Microbiol. 14: 205-208.

8. Bradford, M. M. 1976. A rapid and sensitive method for the quantitation of microgram quantities of protein utilizing the principle of protein-dye binding. Anal. Biochem. 72:248-254.

9. Cato, E. P., D. E. Hash, L. V. Holdeman, and W. E. C. Moore. 1982. Electrophoretic study of Clostridium species. J. Clin. Microbiol. 15:688-702.

10. Charbonnier, F., G. Erauso, T. Barbeyron, D. Prieur, and P. Forterre. 1992. Evidence that a plasmid from a hyperthermophilic archaebacterium is relaxed at physiological temperatures. J. Bacteriol. 174:6103-6108.

11. Cord-Ruwisch, R. 1985. A quick method for the determination of dissolved and precipitated sulfides in cultures of sulfate-reducing bacteria. J. Microbiol. Methods 4:33-36.

12. Corliss, J. B., J. Dymond, L. I. Gordon, J. M. Edmond, R. P. Von Herzen, R. D. Ballard, K. Green, D. Williams, A. Bainbridge, K. Crane, and T. H. Van Andel. 1979. Submarine thermal springs on the Galapagos Rift. Science 203:1073-1083.

13. Deming, J. W., and J. A. Baross. 1993. Deep-sea smokers: windows to a subsurface biosphere? Geochim. Cosmochim. 57:3219-3229.

14. De Rosa, M., A. Gambacorta, A. Trincone, A. Basso, W. Zillig, and I. Holz. 1987. Lipids of Thermococcus celer, a sulfur-reducing archaebacterium: structure and biosynthesis. Syst. Appl. Microbiol. 9:1-5.

15. Di Ruggiero, J., F. T. Robb, H. H. Klump, K. M. Borges, M. Kessel, X. Mai, and M. W. W. Adams. 1993. Characterization, cloning and in vitro expression of the extremely thermostable glutamate dehydrogenase from the hyperthermophilic archaeon, ES4. J. Biol. Chem. 268:17767-17774.

15a.Erauso, G. Unpublished data.

16. Erauso, G., A. Godfroy, G. Raguénès, and D. Prieur. Plate cultivation techniques for strictly anaerobic, thermophilic, sulfur-metabolising archaea. In E. M. Fleischmann, A. R. Place, F. T. Robb, and H. J. Schreier (ed.), Archaea: a laboratory manual, in press. Cold Spring Harbor Laboratory Press, Cold Spring Harbor, N.Y.

17. Erauso, G., A. L. Reysenbach, A. Godfroy, J. R. Meunier, B. Crump, F. Partensky, J. A. Baross, V. Marteinsson, G. Barbier, N. R. Pace, and D. Prieur. 1993. Pyrococcus abyssi sp. nov., a new hyperthermophilic archaeon isolated from a deep-sea hydrothermal vent. Arch. Microbiol. 160:338349 .

18. Fiala, G., and K. O. Stetter. 1986. Pyrococcus furiosus sp. nov. represents a new genus of marine heterotrophic archaebacteria growing optimally at $100^{\circ} \mathrm{C}$. Arch. Microbiol. 145:56-61.

19. Fiala, G., K. O. Stetter, H. W. Jannasch, T. A. Langworthy, and J. Madon. 1986. Staphylothermus marinus sp. nov. represents a novel genus of extremely thermophilic submarine heterotrophic archaebacteria growing up to $98^{\circ} \mathrm{C}$. Syst. Appl. Microbiol. 8:106-113.

20. Fouquet, Y., U. Von Stackelberg, J. L. Charlou, J. P. Donval, J. Erzinger, J. P. Foucher, P. Hezig, R. Mühe, S. Soakai, M. Wiedicke, and H. Whitechurch. 1991. Hydrothermal activity and metallogenesis in the Lau back-arc basin. Nature (London) 349:778-781.

21. Grimont, P. A. D., M. Y. Popoff, F. Grimont, C. Colette, and M. Memelin. 
1980. Reproducibility and correlation study of three deoxyribonucleic acid hybridization procedures. Curr. Microbiol. 4:325-330.

22. Hoaki, T., M. Nishijima, M. Kato, K. Adachi, S. Mizobuchi, N. Hanzawa, and T. Maruyama. 1994. Growth requirements of hyperthermophilic sulfurdependent heterotrophic archaea isolated from a shallow submarine geothermal system with reference to their essential amino acids. Appl. Environ. Microbiol. 60:2898-2904.

23. Hoaki, T., C. O. Wirsen, S. Hanzawa, T. Maruyama, and H. W. Jannasch. 1993. Amino acid requirements of two hyperthermophilic archaeal isolates from deep-sea vents, Desulfurococcus strain SY and Pyrococcus strain GB-D. Appl. Environ. Microbiol. 59:61()-613.

24. Huber, R., P. Stoffer, J. L. Cheminee, H. H. Richnow, and K. O. Stetter. 1990 Hyperthermophilic archaebacteria within the crater and open-sea plume of erupting MacDonald Seamount. Nature (London) 354:179-181.

25. Jannasch, H. W. C. O. Wirsen, S. J. Molyneaux, and T. A. Langworthy. 1988. Extremely thermophilic fermentative archaebacterium of the genus Desulfurococcus from deep-sea hydrothermal vents. Appl. Environ. Microbiol. 54:1203-1209.

26. Jannasch, H. W., C. O. Wirsen, S. J. Molyneaux, and T. A. Langworthy. 1992 Comparative physiological studies of hyperthermophilic archaea isolated from deep-sea hydrothermal vents. Appl. Environ. Microbiol. 58:34723481 .

27. Johnson, J. L. 1984. Nucleic acid in bacterial classification, p. 8-11. In N. R. Krieg and J. G. Holt (ed.), Bergey's manual of systematic bacteriology, vol. I. The Williams \& Wilkins Co., Baltimore.

28. Johnson, J. L. 1985. DNA reassociation and RNA hybridization of bacterial nucleic acids. Methods Microbiol. 18:33-74.

29. Kafatos, F. C., C. W. Jones, and A. Efsratiadis. 1979. Determination of nucleic acid sequence homologies and relative concentrations by a dot hybridization procedure. Nucleic Acids Res. 7:1541-1545.

30. Kobayashi, T., I. S. Kwak, T. Akiba, T. Kudo, and K. Horikoshi. 1994. Thermococcus profundus sp. nov., a new hyperthermophilic archaeon isolated from a deep-sea hydrothermal vent. Syst. Appl. Microbiol. 17:232-236.

31. Laemmli, U. K. 1970. Cleavage of structural proteins during the assembly of the head of bacteriophage T4. Nature (London) 227:680-685.

32. Lanzotti, V., A. Trincone, B. Nicolaus, W. Zillig, M. de Rosa, and A. Gambacorta. 1989. Complex lipids of Pyrococcus and AN1, thermophilic members of the archacbacteria belonging to the Thermococcales. Biochim. Biophys. Acta 1004:44-48.

33. Mandel, M., and J. Marmur. 1968. Use of ultraviolet absorbance-temperature profile for determining the guanine plus cytosine content of DNA. Methods Enzymol. 12:195-206.

34. Marmur, J., and P. Doty. 1962. Determination of the base composition of deoxyribonucleic acid from its thermal denaturation temperature. $J$. Mol Biol. 5:109-118.

35. Mesbah, M., U. Premachandran, and W. B. Whitman. 1989. Precise measurement of the $\mathrm{G}+\mathrm{C}$ content of deoxyribonucleic acid by high-performance liquid chromatography. Int. J. Syst. Bacteriol. 39:159-167.

36. Miroshnichenko, M. L., E. A. Bonch-Osmolovskaya, A. Neuner, N. A. Kostrikina, N. A. Chernych, and V. A. Alekseev. 1989. Thermococcus stetteri sp. nov., a new extremely thermophilic marine sulfur-metabolizing archaebacterium. Syst. Appl. Microbiol. 12:257-262.

37. Morikawa, M. Y. Izawa, N. Rashid, T. Hoaki, and T. Imanaka. 1994. Purification and characterization of a thermostable thiol protease from a newly isolated hyperthermophilic Pyrococcus sp. Appl. Environ. Microbiol. 60: $4559-4566$.

38. Neuner, A., H. W. Jannasch, S. Belkin, and K. O. Stetter. 1990. Thermococcus litoralis sp. nov.: a new species of extremely thermophilic marine archaebacteria. Arch. Microbiol. 153:205-207.

39. Pledger, R. J., and J. A. Baross. 1989. Characterization of an extremely thermophilic archaebacterium from a black smoker polychaete (Paralvinella sp.) at Juan de Fuca Ridge. Syst. Appl. Microbiol. 12:249-256.
40. Pledger, R. J., and J. A. Baross. 1991. Preliminary description and nutritional characterization of a chemoorganotrophic archaebacterium growing at up to $110^{\circ} \mathrm{C}$ isolated from a submarine hydrothermal vent environment. J. Gen. Microbiol. 137:203-211.

41. Pley, U., J. Schipka, A. Gambacorta, H. W. Jannasch, H. Fricke, R. Rachel, and K. O. Stetter. 1991. Pyrodictium abyssi sp. nov. represents a novel heterotrophic marine archaeal hyperthermophile growing at $110^{\circ} \mathrm{C}$. Syst. Appl. Microbiol. 14:245-253.

42. Prieur, D. 1992. Physiology and biotechnological potential of deep-sea bacteria, p. 163-197. In R. A. Herbert and R. J. Sharp (ed.), Molecular biology and biotechnology of extremophiles. Blackie, London.

43. Prieur, D., G. Erauso, and C. Jeanthon. 1995. Hyperthermophilic life at deep-sea hydrothermal vents. Planet. Space Sci. 43:115-122.

44. Reysenbach, A. L., and J. W. Deming. 1991. Effects of hydrostatic pressure on growth of hyperthermophilic archaebacteria from Juan de Fuca Ridge. Appl. Environ. Microbiol. 57:1271-1274.

45. Ross, H. N. M., D. D. Collins, B. J. Tindall, and W. D. Grant. 1981. A rapid procedure for the detection of archaebacterial lipids in halophilic bacteria. J. Gen. Microbiol. 131:165-173.

46. Schönheit, P., and T. Schäfer. 1995. Metabolism of hyperthermophiles. World J. Microbiol. Biotechnol. 11:26-57.

47. Stetter, K. O., H. König, and E. Stackebrandt. 1983. Pyrodictitum gen. nov., a new genus of submarine disc-shaped sulphur reducing archaebacteria growing optimally at $105^{\circ} \mathrm{C}$. Syst. Appl. Microbiol. 4:535-551.

48. Wayne, L. G., D. J. Brenner, R. R. Colwell, P. A. D. Grimont, O. Kandler, M. I. Krichevsky, L. H. Moore, W. E. C. Moore, R. G. E. Murray, E. Stackebrandt, M. P. Starr, and H. G. Truper. 1987. Report of the Ad Hoc Committee on Reconciliation of Approaches to Bacterial Systematics. Int. Syst. Bacteriol. 37:463-464.

49. White, D. C., R. J. Bobbie, J. D. King, J. S. Nickels, and P. Amoe. 1979. Lipid analysis of sediments for microbial biomass and community structure, p. 87-103. In C. D. Liitchfield and P. L. Seyfried (ed.), Methodology for biomass determinations and microbial activities in sediments. American Society for Testing and Materials, Washington, D.C.

50. Woese, C. R., O. Kandler, and M. L. Wheelis. 1990. Towards a natural system of organisms: proposal for the domains Archaea, Bacteria, and Eucarya. Proc. Natl. Acad. Sci. USA 87:4576-4579.

51. Zillig, W. 1992. The order Thermococcales, p. 702-706. In A. Balows, H. G. Truper, M. Dworkin, W. Harder, and K. H. Schleifer (ed.), The prokaryotes, 2nd ed. Springer-Verlag, Heidelberg, Germany.

52. Zillig, W., I. Holtz, D. Janekovic, H.-P. Klenk, E. Imsel, J. Trent, S. Wunderl, V. H. Forjaz, R. Coutinho, and T. Ferreira. 1990. Hyperthermus butylicus, a hyperthermophilic sulfur-reducing archaebacterium that ferments peptides. J. Bacteriol. 172:3959-3965.

53. Zillig, W. I. Holtz, D. Janekovic, W. Schafer, and W. D. Reiter. 1983. The archaebacterium Thermococcus celer represents a novel genus within the thermophilic branch of the archeabacteria. Syst. Appl. Microbiol. 4:88-94.

54. Zillig, W., I. Holtz, H. P. Klenk, J. Trent, S. Wunderl, D. Janekovic, E. Imsel, and B. Haas. 1987. Pyrococcus woesei, sp. nov., an ultra-thermophilic marine archaebacterium, representing a novel order, Thermococcales. Syst. Appl. Microbiol. 9:62-70.

55. Zillig, W., I. Holtz, and S. Wunderl. 1991. Hyperthermus butylicus gen. nov., sp. nov., a hyperthermophilic, anaerobic, peptide-fermenting, facultatively $\mathrm{H}_{2} \mathrm{~S}$-generating archaebacterium. Int. J. Syst. Bacteriol. 41:169-170.

56. Zillig, W., K. O. Stetter, D. Prangishwilli, W. Schafer, S. Wunderl, D. Janekovic, I. Holz, and P. Palm. 1982. Desulfurococcaceae, the second family of extremely thermophilic, anaerobic sulfur-respiring Thermoproteales. Zentralbl. Bakteriol. Parasitenkd. Infektionskr. Hyg. Abt. 1 Orig. 3:304-317.

57. Zillig, W., K. O. Stetter, S. Wunderl, W. Shulz, H. Priess, and J. Scholz. 1980. The Sulfolobus-"Caldariella" group: taxonomy on the basis of the structure of DNA-dependent RNA-polymerases. Arch. Microbiol. 1980:125259. 